\title{
Land cover changes in the Air Telang Protected Forest, South Sumatra, Indonesia (1989-2013)
}

\author{
SYAIFUL EDDY ${ }^{1, \vartheta}$, ISKHAQ ISKANDAR ${ }^{2}$, MOH. RASYID RIDHO ${ }^{2}$, ANDY MULYANA ${ }^{3}$ \\ ${ }^{1}$ Department of Biology, Faculty of Mathematics and Natural Sciences, Universitas PGRI Palembang, J1. Jend. A. Yani, 9/10 Ulu, Palembang 30251, \\ South Sumatra, Indonesia. Tel.+62-711-510043, Fax.+62-711-514782, ”email: syaifuleddy@gmail.com \\ ${ }^{2}$ Faculty of Mathematics and Natural Sciences, Universitas Sriwijaya. Indralaya, Ogan Ilir 30862, South Sumatra, Indonesia \\ ${ }^{3}$ Faculty of Agriculture, Universitas Sriwijaya. Indralaya, Ogan Ilir 30862, South Sumatra, Indonesia.
}

Manuscript received: 10 August 2017. Revision accepted: 3 October 2017.

\begin{abstract}
Eddy S, Iskandar I, Ridho MR, Mulyana A. 2017. Land cover changes in the Air Telang Protected Forest, South Sumatra, Indonesia (1989-2013). Biodiversitas 18: 1538-1545. The Air Telang Protected Forest (ATPF) is a mangrove forest in the Banyuasin District, South Sumatra, Indonesia. It has an area of about 12,660.87 ha. In fact, that the ATPF area has been converted into aquacultures, plantations, agricultural lands, settlements and ports during recent decades. The objective of this study is to identify the land cover changes in the ATPF from 1989 through 2013 using satellite remote sensing data. Three Landsat satellite imageries for 1989, 2001 and 2013 have been used to build maps and to predict the land cover changes in the study area. A ground-truthing verification was done to increase the accuracy of image classification in each region. The results showed that the anthropogenic forcing had caused significant degradation of primary mangrove forest in the ATPF from 1989 to 2013. This forcing was categorized as mangrove conversion into coconut plantations, oil palm plantations, aquacultures, farms, ports, and settlements. Of these six conversions, the coconut plantations, oil palm plantations and aquacultures have potential tendencies to increase construction that could threaten the existence of mangrove forest in ATPF. It was found that during 2013, the coconut plantations, oil palm plantations, and aquacultures accounted for about 18.0\% (2,278.62 ha), 4.7\% (591.87 ha) and 3.1\% (386.18 ha) of mangrove forest changes, respectively.
\end{abstract}

Keywords: Air Telang Protected Forest, degradation, land cover changes, mangrove forest

\section{INTRODUCTION}

Mangrove forests have grown in the tidal zones such as swamps, lagoons, rivers and coastal estuaries in the tropical and subtropical regions and they are tolerant to salt water (Piou et al. 2006; Fatoyinbo et al. 2008; Strauch et al. 2012; Motamedi et al. 2014). They have several important functions, such as in carbon transport, primary productivity, nitrogen, and phosphorus transport, creating a niche as well as protecting coastal regions from disturbances (Lee et al. 2006; Fatoyinbo et al. 2008; Mukherjee et al. 2014).

Mangrove forests in Indonesia are among the largest ones in the world which consist of an area of around 3.2 million ha or $22.6 \%$ of the total mangrove forests in the world (DasGupta and Shaw 2013; Kusmana 2014). In addition, around $60 \%$ of the total mangrove forests in Southeast Asia are located in Indonesia (Giesen et al. 2007). However, the condition of mangrove forests in Indonesia continues to degenerate both quantitatively and qualitatively. It is mostly due to their conversion into infrastructures, farms, aquacultures, plantations, settlements, and mines, as well as extraction of their timber for industries, fuels and charcoals (Thu and Populus 2007; Giri et al. 2014; Jones et al. 2014; Komiyama 2014; Mukherjee et al. 2014).

According to Soepraptohardjo et al. (1979), there was about 230,260 ha of mangrove forests in Southern Sumatra. However, recent data from the National Coordinating
Agency for Survey and Mapping, Republic of Indonesia (2009) showed that the remaining mangrove forests in South Sumatra were only around 149,707 ha. This data indicates a continuous degradation in which South Sumatra region lost about $35 \%$ of its mangrove forests within those about 30 years.

One of the mangrove forest areas in South Sumatra is Air Telang Protected Forest (ATPF). It is located in the Banyuasin District covering an area of about 12,660.87 ha. A study by Department of Forestry and Plantation of Banyuasin District (2010) has shown that about 4,272.63 ha of the ATPF areas have been converted into plantations, aquacultures, farms, and settlements. In addition, passenger and cargo ports were recently built in Tanjung Api-api located close to the ATPF. Moreover, since 2014, the area in the vicinity of the ATPF has been designated by the Central Government of the Republic of Indonesia as a Special Economic Zone (SEZ) in South Sumatra. Consequently, all economic activities in this area will influence the quality and quantity of the mangrove forests due to more abrasion, increased seawater intrusion and decreased self-maintenance as coastal processes (Berger et al. 2008; Onrizal and Kusmana 2008). In addition, overlapping interests in the mangrove forest will create ambiguous ownership leading to a complex management of the mangrove forests (Walters et al. 2008).

In this paper, three Landsat satellite imageries taken in 1989, 2001 and 2013 have been used to build the ATPF map. A ground-truthing verification was carried out to 
evaluate the classification of each region. This research is expected to contribute to the formulation of management strategy and restoration program of the mangrove forest. Note that the formulation of effective strategies, monitoring of environmental changes and management plans of mangrove forest require spatial information which is related to the fragmentation of mangrove forests through mapping of mangrove forest entities accurately, reliably and efficiently ( $\mathrm{Li}$ et al. 2013; Jayanth et al. 2016). In addition, mangrove forest restoration requires data of site conditions and monitoring of ecosystem level as integrated components of restoration projects (Bosire et al. 2008).

\section{MATERIALS AND METHODS}

\section{Study area}

This study was conducted in the mangrove forest of the ATPF area in Banyuasin District, South Sumatra, Indonesia with an area of about $12,660.87$ ha (Figure 1). The study area is directly adjacent to the Bangka Strait and the Banyuasin River in the North, and to Muara Telang District in the South. To the East, it is bordered by the Muara Telang District and the Banyuasin II District, while the Banyuasin River is the boundary to the West. According to Department of Forestry and Plantation of Banyuasin District (2010), ATPF region has a flat coastal area, which is a tidal marsh area with slopes between $0-8 \%$ and a height of 0-7 $\mathrm{m}$ above sea level. Various types of mangrove forest flora are commonly found in this area, such as Rhizophora sp, Avicennia sp, Sonneratia alba and Bruguiera gymnorhiza. Species of fauna that exist in this area include, among others, Hilobatus sybactilus, Crocodylus prosus, Sus barbatus, Eugretta sp and Maccaca fascicularis. The study area has been partially converted into plantations, agricultural lands, settlements, and aquacultures. Recently, there are two ports, marine and ferry terminals that had been built near the study area. These ports are located in Tanjung Api-Api, which are situated on the western coast of the study area. The Tanjung Api-Api region has been declared as the SEZ, which consists of two zones located in the District of Banyuasin II and District of Tanjung Carat.

\section{Data collection}

In this study, three Landsat satellite imageries from 1989, 2001 and 2013 were collected. Specifications of the satellite data acquired for land cover change analysis are given in Table 1. The map coordinate system used UTM coordinate system (zone $48 \mathrm{~S}$ ). Some 22 locations were physically visited for ground-truthing purpose using the Geographical Positioning System (Table 2). These sites were used to support the image classification and to improve the accuracy of the classification results. In addition, we also used forestry thematic maps and land cover maps that were obtained from several related agencies in Indonesia such as Forestry Agency and Agency for Geospatial Information.
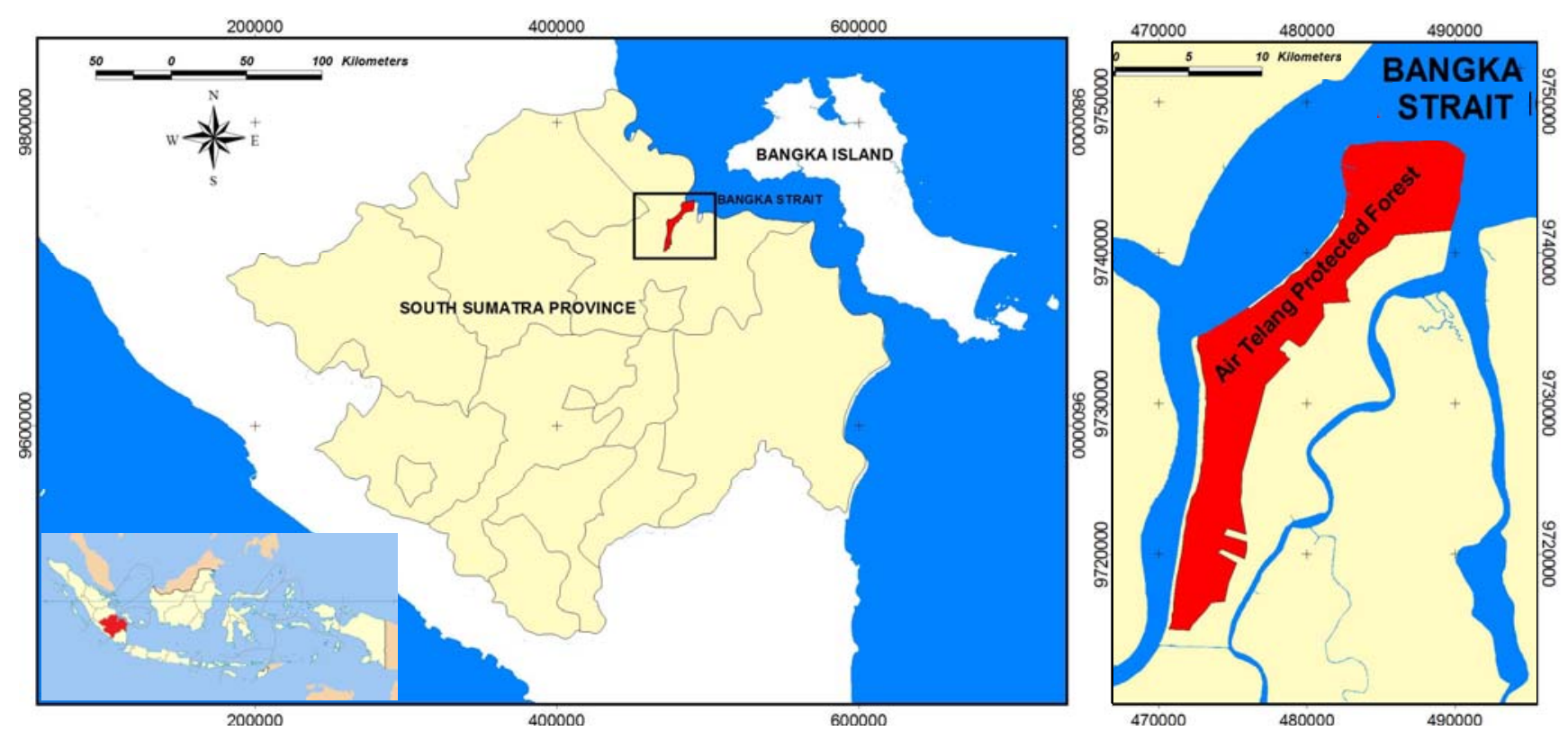

Figure 1. Location of the study area in the Air Telang Protected Forest, South Sumatra, Indonesia (red color). Map coordinate system: UTM projection, zone $48 \mathrm{~S}$, datum WGS 1984 
Table 1. Specifications of satellite data

\begin{tabular}{lllll}
\hline Data & Date of acquisition & Bands & Resolution (m) & Source \\
\hline Landsat 5 TM & 17 May 1989 & Multi-spectral & 250 & USGS glovis \\
Landsat 7 ETM+ & 06 June 2001 & Multi-spectral & 250 & USGS glovis \\
Landsat 8 ETM+ & 17 January 2013 & Multi-spectral & 250 & USGS glovis \\
\hline
\end{tabular}

Table 2. Locations of the ground-truth sites in the study area

\begin{tabular}{lll}
\hline UTM coordinate & & Existing condition \\
\hline 474170 & 9719249 & Secondary forest \\
480305 & 9737692 & Secondary forest \\
482109 & 9737782 & Secondary forest \\
482552 & 9738829 & Secondary forest \\
475365 & 9734232 & Secondary forest \\
478382 & 9737886 & Primary forest \\
481564 & 9740503 & Primary forest \\
482001 & 9741427 & Primary forest \\
477885 & 9736030 & Primary forest \\
474740 & 9720742 & Oil palm plantation \\
475256 & 9722749 & Oil palm plantation \\
474822 & 9723408 & Coconut plantation \\
475045 & 9723893 & Coconut plantation \\
475347 & 9726851 & Coconut plantation \\
475537 & 9727279 & Coconut plantation \\
476038 & 9728477 & Coconut plantation \\
479467 & 9734060 & Coconut plantation \\
478422 & 9735845 & Aquaculture \\
482334 & 9738404 & Aquaculture \\
480534 & 9737243 & Shrubs \\
478438 & 9737733 & Port \\
488874 & 9748356 & Water body \\
\hline
\end{tabular}

Table 3. Land use classification in the Air Telang Protected Forest, South Sumatra, Indonesia

\begin{tabular}{|c|c|}
\hline Class name & Description \\
\hline Primary forest & $\begin{array}{l}\text { Dominated by stands of true mangrove, } \\
\text { which consist of Rhizophora apiculata, } \\
\text { Avicennia alba, Bruguiera cylindrica, } \\
\text { Excoecaria agallocha, Nypa fruticans and } \\
\text { Xylocarpus granatum. }\end{array}$ \\
\hline Secondary forest & A mixture of mangroves and shrubs. \\
\hline Coconut plantation & Dominated by stands of coconuts. \\
\hline Oil palm plantation & Dominated by stands of oil palms. \\
\hline Shrubs & Dominated by cover plants. \\
\hline Aquaculture & Fish and shrimp farming. \\
\hline Port & $\begin{array}{l}\text { The anchored place of the large ship to } \\
\text { transport passengers and goods. }\end{array}$ \\
\hline Water body & The land is still inundated due to tides. \\
\hline
\end{tabular}

\section{Data analysis}

The analysis and classification of land cover changes in the ATPF were conducted by using Geographic Information System (GIS) analysis with ArcView 3.3. The classification was based on the type of land use and the density of the canopy. The land use types were classified into (1) primary forest, (2) secondary forest, (3) coconut plantation, (4) oil palm plantation, (5) shrubs, (6) aquaculture, (7) port, and (8) water body (Table 3).

The GIS analysis was divided into four steps, namely pre-processing, processing, image classification and field survey. In the pre-processing step, Landsat imagery at a scale of 1: 250,000 is rectified using spatial map. This rectification process included a rotation, translation and geometric correction into the UTM coordinate system (zone $48 \mathrm{~S}$ ). In addition, an atmospheric correction was also performed in this step to minimize the variation of the spectral object due to the influence of atmospheric particles and solar radiation.

In the processing step, an image sharpening was conducted to increase the amount of information that can be interpreted visually from the images. In this study, the False Color Composite (FCC) was used to define the mangrove forest with the RGB (Red, Green, Blue) composite with band combination of 4, 5 and 3. Further, the land use and land cover mapping were performed through an on-screen digitization. The next step was image classification. The images were classified using supervised classification method (visual interpretation). This method requires the knowledge and experience of researchers in the study area. Visual interpretation of satellite imagery is an effective method for documenting changes in land use and land cover (Butt et al. 2015). The supervised classification method was also employed by Boori et al. (2015) to analyze land cover disturbance caused by tourism activities. Meanwhile, Ghebrezgabher et al. (2016) used this method to analyze the forest cover change in Eritrea, Africa. Finally, a field survey was conducted to verify the information on a land cover as well as to check the boundaries of each land cover types. The results of field verification were used to perform re-classification in order to obtain the final land cover map.

\section{RESULTS AND DISCUSSION}

\section{Qualitative changes in land cover}

Qualitative changes in land cover in the ATPF during the period of 1989-2013 are shown in Figure 2. It was found that there has been a continuous reduction in the primary forest area. Nevertheless, there has been an increase of primary forest area in the northern and western parts of the study area due to enhanced sedimentation in the Banyuasin River. The siltation in the tidal zone for a long time has formed new lands in the coastal area of Banyuasin River (Department of Forestry and Plantation of the 
Banyuasin District 2010). Although the primary forest area has increased due to the sedimentation, yet it is still not significant compared to the conversion rate of the primary forest into the coconut plantations, oil palm plantations, and aquacultures as shown in Figure 2. Furthermore, the increase of the secondary forests and shrubs were mainly caused by the degradation of primary forest that was neglected by the community for a long time.

The oil palm plantation did not exist in 1989, but it had been detected by 2001. In 2013, plantations were significantly found in the southern part of the ATPF in 2013. Similarly, the ports have been identified by 2013 . The aquaculture areas have been identified by 2001 and by the year 2013, the number has increased. The decrease of water body areas (refer to Figure 2) occurred continuously due to an intensive sedimentation in the tidal zone both in the northern and western parts of the study area, which in turn could lead to the formation of new lands.

\section{Quantitative changes in land cover}

The quantitative changes in land cover in the ATPF area are listed in Table 4 . The area of primary forests had decreased during the period 1989-2013. The area of primary forests identified in 1989 was about 9,219.82 ha $(72.8 \%)$, declined to $8,131.49$ ha $(64.2 \%)$ in 2001 , and then to $6,585.28$ ha $(52.0 \%)$ in 2013 . Furthermore, the total area of secondary forests identified in 2001 was about 2,589.31 ha $(20.5 \%)$, and it slightly decreased in 2013 to $2,389.52$ ha (18.9\%).

The total area of coconut plantations had doubled from $1,167.80$ ha $(9.2 \%)$ in 2001 to $2,278.62$ ha $(18.0 \%)$ in 2013. The oil palm plantations had been identified only by 2013 with a total area of about 591.87 ha (4.7\%). In 1989, the total area of shrubs was identified as large as 318.11 ha $(2.5 \%)$. However, by 2013 , it had been continuously decreased to less than $1 \%$ of the total area of the ATPF. Similarly, the water bodies have continuously decreased from 1989 to 2013. In 1989, the total area of the water bodies was about 718.01 ha $(5.7 \%)$ and then decreased to 354.63 ha $(2.8 \%)$ in 2013. Meanwhile, the total area of aquacultures has increased from 238.03 ha (1.9\%) in 2001 to 386.18 ha $(3.1 \%)$ in 2013 . The ports were identified only in 2013 with an area of about 37.72 ha $(0.3 \%)$.
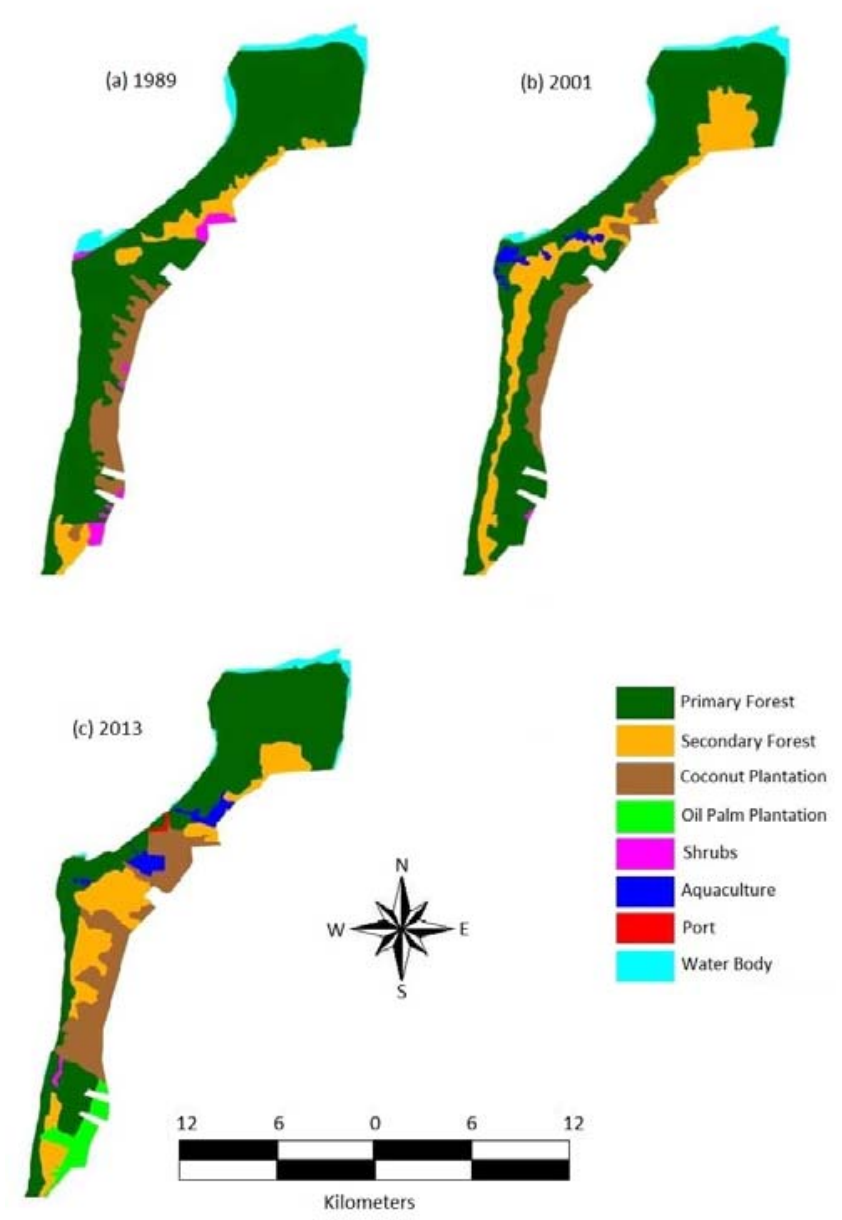

Figure 2. The land cover changes in the Air Telang Protected Forest region, South Sumatra, Indonesia in 1989, 2001 and 2013

Table 4. Total area of each type of land cover in the Air Telang Protected Forest, South Sumatra, Indonesia in 1989, 2001 and 2013, and changes in land cover over the period of 1989 to 2001 and 2001 to 2013

\begin{tabular}{|c|c|c|c|c|c|c|c|c|c|c|c|c|}
\hline \multirow{2}{*}{$\begin{array}{l}\text { Land cover } \\
\text { Type }\end{array}$} & \multicolumn{2}{|c|}{ Area at 1989} & \multicolumn{2}{|c|}{ Area at 2001} & \multicolumn{2}{|c|}{ Area at 2013} & \multicolumn{3}{|c|}{ Changes (1989-2001) } & \multicolumn{3}{|c|}{ Changes (2001-2013) } \\
\hline & (ha) & $(\%)$ & (ha) & $(\%)$ & (ha) & $(\%)$ & (ha) & $(\%)$ & Size & (ha) & $(\%)$ & Size \\
\hline Primary forest & $9,219.82$ & 72.8 & 131.49 & 64.2 &, 585.28 & 52.0 & $1,088.33$ & 11.8 & dec & $1,546.21$ & 19.0 & dec \\
\hline $\mathrm{Sec}$ & 1,063 & 8.4 & 2 , & 20.5 & 2 & 18.9 & $1,526.18$ & 143.6 & inc & 79 & 7.7 & $\operatorname{dec}$ \\
\hline $\mathrm{Coc}$ & $1,341.80$ & 10.6 & $1,167.80$ & 9.2 & 2,27 & 18.0 & 174.00 & 13.0 & dec & 1,11 & 95.1 & inc \\
\hline Oil & - & - & - & - & 591.87 & 4.7 & - & - & 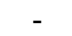 & & 100.0 & $\mathrm{nc}$ \\
\hline Shrt & 318.11 & 2.5 & 15.2 & 0.1 & 37.05 & 0.3 & 302.86 & 95.2 & dec & & 143.0 & $\mathrm{nc}$ \\
\hline Aquac & - & - & 238.03 & 1.9 & 386.18 & 3.1 & 238.03 & 100.0 & inc & 148.15 & 62.2 & inc \\
\hline Port & - & - & - & - & 37.72 & 0.3 & - & - & - & 37.72 & 100.0 & inc \\
\hline Water body & 718.01 & 5.7 & 518.99 & 4.1 & 354.63 & 2.8 & 199.02 & 27.7 & dec & 164.36 & 31.7 & dec \\
\hline Total & $12,660.87$ & 100.0 & $12,660.87$ & 100.0 & $12,660.87$ & 100.0 & & & & & & \\
\hline
\end{tabular}

Note: dec $=$ decrease, inc $=$ increase. 


\section{Degradation of mangrove cover}

Protected forest is an area that supports an ecosystem by controlling the water system, preventing flooding, controlling erosion, preventing seawater intrusion and maintaining soil fertility. The ATPF is one of the protected forests that experienced significant degradation. In this study, we found that the ATPF area has been affected by the anthropogenic activities. These anthropogenic activities include coconut and oil palm plantations, aquacultures and ports (Figure 3 ). In addition, the forest area continued to be converted into settlements and area for agricultural activities. In the ATPF area, the settlements have existed since the 1970s. In fact, the construction of highways has contributed to the increased in the number of the population in this area. The people in this study area have initiated construction of coconut plantations since 1972. The aquaculture activity has existed since 1987, and in 1997 the total area of the aquacultures rapidly increased due to an intensive construction of aquacultures by a private company. Meanwhile, the oil palm plantations have started since 2008 after the construction of the highway. The physical infrastructure developments and other anthropogenic activities have several negative impacts on the environment, such as decrease of water quality and dynamic shifts of mangrove vegetation that reduced fish production (Satyanarayana et al. 2013).

Primary forest cover (Figure 2, Figure 4a and Table 4) has decreased for the last 24 years, i.e., between 19892013. In the first period of 1989-2001, the primary forest cover decreased by about $1,088.33$ ha $(11,8 \%)$ or 90.69 ha per year. Meanwhile, in the second period (2001-2013), the decrease occurred in a larger quantity, by 1,546.21 ha $(19.0 \%)$ or 128.85 ha per year. The decline in the primary forest cover was mainly due to the conversion of the mangrove forests into oil palm plantations, coconut plantations and aquacultures with the percentage area in 2013 being $4.7 \%, 18.0 \%$, and $3.1 \%$, respectively.

There have been transformations of some areas in the ATPF into new primary forest area (Figure 2 and Table 4). These transformations were contributed by two succession mechanisms, the re-vegetation in the tidal zones (new land) and the succession of secondary forests into primary forest. The first succession mechanism, the primary succession, has taken place due to sedimentation that resulted in the formation of new land in the tidal zone of the Banyuasin river. According to Fromard et al. (2004) and Setyawan et al. (2005), the presence of mud bank is an early stage of mangrove colonization in a new land. Mangrove colonization has begun to occur as the sediment becomes stable due to the tidal cycle. Mangrove propagules were carried out by tidal currents into the new land area and adapted to grow therein. This process would result in a new cycle in the ecosystem of mangrove forest. However, anthropogenic pressures would eliminate the aerial root masses which in turn, disturb the distribution of mangrove propagules (Di Nitto et al. 2008). Furthermore, seaward mangroves could migrate landward as a result of the rise of sea level, increase in salinity, and increases in the frequency, period and depth of inundation (Gilman et al. 2007).
Secondly, the secondary succession of the secondary forest into primary forest happened in the northern area of the ATPF between 2001-2013. Vegetation dynamics could be influenced by anthropogenic effect, changes in the hydroedaphic condition and species interaction (Iftekhar and Saenger 2008). Additionally, the structure and composition of mangrove vegetation were influenced by geomorphological and environmental settings (Cunha-Lignon et al. 2009).

The secondary forest cover (Figure 2, Figure $4 \mathrm{~b}$ and Table 4) increased significantly by $1,526.18$ ha $(143.6 \%)$ or 127.18 ha per year in the first period. This increase was due to land clearance of primary forests for agricultural lands and plantations, as well as timber utilization. During the second period, there was a slight decrease by 199.79 ha $(7.7 \%)$ or 16.65 ha per year in the secondary forest cover. This decline was due to the conversion of secondary forests into coconut plantations, oil palm plantations, and aquacultures. Furthermore, some secondary forest areas, such as those in the north region, has been transformed into primary forests through natural succession.

The land area used for coconut plantations and aquaculture have increased significantly by $1,110.82$ ha $(95.1 \%)$ and 148.15 ha $(62.2 \%)$, respectively, during the period of 2001 to 2013. (Table 4). Meanwhile, the oil palm plantations which have been initiated by 2013 span a total area of 591.87 ha or $4.7 \%$ of the ATPF area. From 2001 to 2013, degradation in the ATPF area caused by the construction of the coconut plantations, aquacultures, and oil palm plantations reached 92.57 ha, 12.35 ha and 49.32 ha per year, respectively. According to our analysis, the oil palm plantations are expected to accelerate the reduction of mangrove forest cover in the ATPF area.

According to data from Department of Forestry and Plantation of Banyuasin District, disturbances occurred in the ATPF area in 2010 were contributed by the forest conversion into coconut plantations $(3,289.73 \mathrm{ha})$, oil palm plantations (521.98 ha), aquacultures (377.81 ha), agricultural lands (26.11 ha), and settlements (57.00 ha). Coconut plantations, oil palm plantations, and aquacultures contributed significantly to the degradation of mangrove forests in ATPF. According to Laulikitnont (2014), the existence of aquacultures, plantations and agricultural land in mangrove forests area are the main cause of the forests in Indonesia. Similarly, several previous studies showed that the decrease in mangrove forest number in several countries in the world are caused by aquacultures, plantations and agricultures (Thu and Populus 2007; Donders et al. 2008; Ilman et al. 2011; Bryan et al. 2013; $\mathrm{Li}$ et al. 2013; Nfotabong-Atheull et al. 2013; Jones et al. 2014; Komiyama 2014).

Some studies showed significant vegetation changes due to anthropogenic activities. According to Hansen et al. (2013), Indonesia has the highest rate of forest loss, which is about $1,021 \mathrm{~km}^{2} /$ year during 2000 to 2012 . Rahman et al. (2013) have shown a rapid land use change in the Delta Mahakam, in which the total mangrove loss in that area reached 21,000 ha during 2000 to 2010 . Using modeling study, Elz et al. (2015) have shown a significant land cover change in the protected forest in Berbak, Jambi Province. They argued that by the year 2040, land cover in this 
protected forest will be reduced by about $25 \%$. Similar rapid land use and land cover changes were also found in the neighboring country of Malaysia. The vegetation cover change in swamp forests of Peninsular Malaysia, Sumatra and Borneo due to land conversion into palm plantations spanned an area of 3.1 Mha in 2015 (Miettinen et al. 2016).

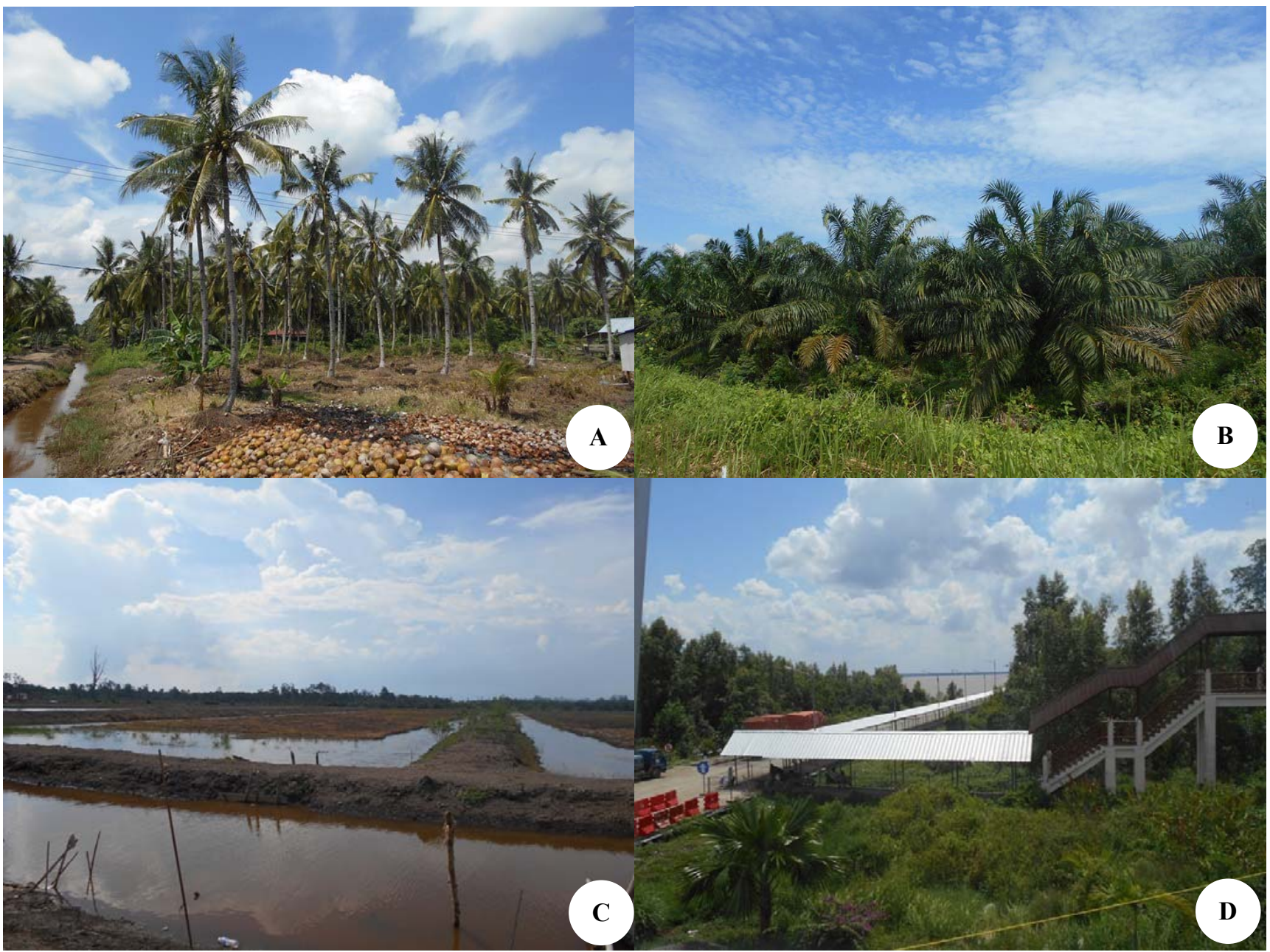

Figure 3. Conversion of mangrove forests in the Air Telang Protected Forest, South Sumatra, Indonesia by coconut plantations (A), oil palm plantations (B), aquacultures (C), and ports (D)

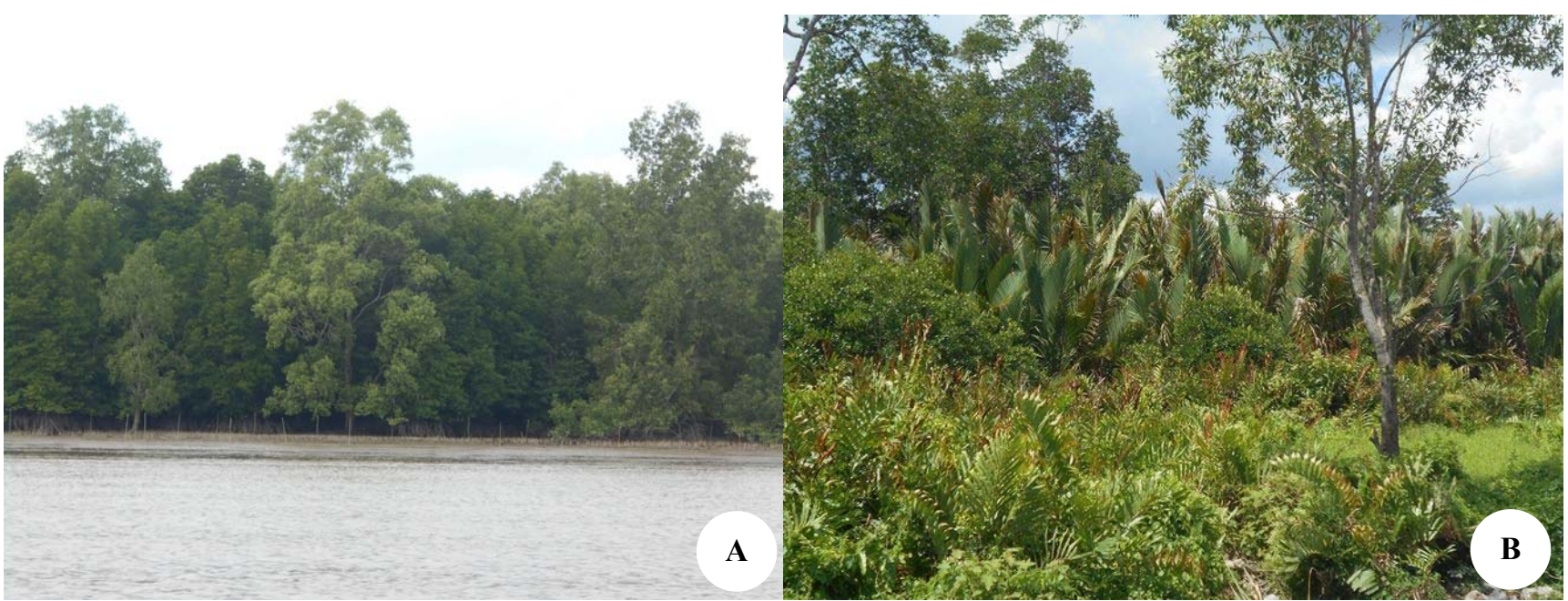

Figure 4. Primary forest (A) and secondary forest (B) conditions in the Air Telang Protected Forest, South Sumatra, Indonesia 
Anthropogenic activities in ATPF has become more complicated because the Government designated the area as a SEZ. The SEZ consisted of two zones that included Banyuasin II District and Tanjung Carat District. Therefore, it is imperative that the Government takes a stand to implement restoration of the area to ensure the sustainability of the mangrove forests. Mangrove forest restoration has a significant potential to increase the forest resources, protect the tropical coastlines, and enhance fisheries biodiversity and productivity (Kairo et al. 2001).

This study used a supervised classification method to analyze the land cover changes in the ATPF area using time series of satellite remote sensing data. We demonstrated that anthropogenic forcing in the forms of coconut plantations, oil palm plantations, aquacultures, ports, settlements and agricultural lands was the primary cause of degradation of the primary mangrove forest in the ATPF during the period of 1989-2013. Furthermore, the anthropogenic forcing that shows an increasing trend includes coconut plantations, oil palm plantations, and aquacultures, which reached $18.0 \%$ (2,278.62 ha), $4.7 \%$ $(591.87 \mathrm{ha})$ and $3.1 \%$ (386.18 ha) of the total of the land cover changes in 2013, respectively. In addition, our study identifies the formation of new primary forest in several regions of the ATPF, which are contributed by the revegetation in the tidal zones and the secondary forest succession into the primary forest. Furthermore, the area of the newly formed primary forest was much smaller compared to the area that was lost as a result of primary forests conversion due to anthropogenic activities. This study could be used as a reference for other researchers to investigate issues related to anthropogenic land cover changes of mangrove forests.

\section{ACKNOWLEDGEMENTS}

The first author would like to express thanks to the Universitas PGRI Palembang and the Ministry of Research, Technology and Higher Education, Republic of Indonesia, for providing the funding for this research. The second author is also indebted to the Universitas Sriwijaya for its support through "Riset Kolaborasi Internasional" and to the Ministry of Research, Technology and Higher Education, the Republic of Indonesia through "Hibah Kompetensi (No. 023/Sp2H/LT/DPRM/II/2016)".

\section{REFERENCES}

Berger U, Rivera-Monroy VH, Doyle TW, Dahdouh-Guebas F, Duke NC, Fontalvo-Herazo ML, Hildenbrandt H, Koedam N, Mehlig U, Piou C, Twilley RR. 2008. Advances and limitations of individual-based models to analyze and predict dynamics of mangrove forests: a review. Aquat Bot 89: 260-274.

Boori MS, Voženílek V, Choudhary K. 2015. Land use/cover disturbance due to tourism in Jeseníky Mountain, Czech Republic: a remote sensing and GIS based approuch. Egypt J Remote Sens Space Sci 18: 17-26.

Bosire JO, Guebas FD, Walton M, Crona BI, Lewis RR, Field C, Kairo JG, Koedam N. 2008. Functionality of restored mangroves: a review. Aquat Bot 89: 251-259.
Bryan JE, Shearman PL, Asner GP, Knapp DE, Aoro G, Lokes B. 2013. Extreme differences in forest degradation in Borneo: comparing practices in Sarawak, Sabah, and Brunei. Plos One 8 (7): 1-7.

Butt A, Shabbir R, Ahmad SS, Aziz N. 2015. Land use change mapping and analysis using remote sensing and GIS: a case study of Simly watershed, Islamabad, Pakistan. Egypt J Remote Sens Space Sci 18: 251-259.

Cunha-Lignon M, Coelho-Jr. C, Almeida R, Menghini R, Correa F, Schaeffer-Novelli Y, Cintrỏn-Molero G, Dahdouh-Guebas F. 2009. Mangrove forest and sedimentary processes on the south coast of Sao Paulo State (Brazil). J Coast Res 56: 405-409.

DasGupta R, Shaw R. 2013. Cumulative impacts of human interventions and climate change on mangrove ecosystems of South and Southeast Asia: an overview. J Ecosyst 2013: 1-15.

Department of Forestry and Plantation of the Banyuasin District. 2010. Reports on Disturbances Identification in Air Telang Protected Forest Area, Banyuasin. [Indonesian]

Di Nitto DD, Dahdouh-Guebas F, Kairo JG, Decleir H, Koedam N. 2008. Digital terrain modelling to investigate the effects of sea level rise on mangrove propagule establishment. Mar Ecol Prog Ser 356: 175-188.

Donders TH, Gorissen PM, Sangiorgi F, Cremer H, Wagner-Cremer F, McGee V. 2008. Three-hundred-year hydrological changes in a subtropical estuary, Rookery Bay (Florida): human impact versus natural variability. Geochem Geophys Geosystem 9 (7): 1-15.

Elz I, Tansey K, Page SE, Trivedi M. 2015. Modelling deforestation and land cover transitions of tropical peatlands in Sumatra, Indonesia using remote sensed land cover data sets. Land 4: 670-687.

Fatoyinbo TE, Simard M, Washington-Allen RA, Shugart HH. 2008. Landscape-scale extent, height, biomass, and carbon estimation of Mozambique's mangrove forests with Landsat ETM+ and Shuttle Radar Topography Mission elevation data. J Geophys Res 113: 1-13.

Fromard F, Vega C, Proisy C. 2004. Half a century of dynamic coastal change affecting mangrove shorelines of French Guiana. A case study based on remote sensing data analysis and field surveys. Mar Geol 208: $265-280$

Ghebrezgabher MG, Yang T, Yang X, Wang X, Khan M. 2016. Extracting and analyzing forest and woodland cover change in Eritrea based on landsat data using supervised classification. Egypt J Remote Sens Space Sci 19: 37-47.

Giesen W, Wulffraat S, Zieren M, Scholten L. 2007. Mangrove Guidebook for Southeast Asia. Dharmasarn Co. Ltd., Bangkok.

Gilman E, Ellison J, Coleman R. 2007. Assessment of mangrove response to projected relative sea-level rise and recent historical reconstruction of shoreline position. Environ Monit Assess 124: 105-130.

Giri C, Long J, Abbas S, Murali RM, Qamer FM, Pengre B, Thau D. 2014. Distribution and dynamic of mangrove forests of South Asia. J Environ Manag 2014: 1-11.

Hansen MC, Potapov PV, Moore R, Hancher M, Turubanova SA, Tyukavina A, Thau D, Stehman, SV, Goetz SJ, Loveland TR, Kommareddy A, Egorov A, Chini L, Justice CO, Townshend JRG. 2013. High-resolution global maps of 21 st-century forest cover change. Sci 342: 850-853.

Iftekhar MS, Saenger P. 2008. Vegetation dynamics in the Bangladesh Sundarbans mangroves: a review of forest inventories. Wetl Ecol Manag 16: 291-312.

Ilman M, Wibisono ITC, Suryadiputra INM. 2011. State of the Art Information on Mangrove Ecosystems in Indonesia. Wetlands International-Indonesia Programme, Bogor.

Jayanth J, Kumar TA, Koliwad S, Krishnashastry S. 2016. Identification of land cover changes in the coastal area of Dakshina Kannada district, South India during the year 2004-2008. Egypt J Remote Sens Space Sci 19: 73-93.

Jones TG, Ratsimba HR, Ravaoarinorotsihoarana L, Cripps G, Bey A. 2014. Ecological variability and carbon stock estimates of mangrove ecosystems in Northwestern Madagascar. For 5: 177-205.

Kairo JG, Dahdouh-Guebas F, Bosire J, Koedam N. 2001. Restoration and management of mangrove systems - a lesson for and from the East African region. S Afr J Bot 67: 383-389.

Komiyama A. 2014. Conservation of mangrove ecosystems through the eyes of a production ecologist. Rev Agric Sci 2: 11-20.

Kusmana C. 2014. Distribution and current status of mangrove forest in Indonesia. In: Faridah-Hanum I, Latiff A, Hakeem KR, Ozturk M (eds) Mangrove Ecosystems of Asia: Status, Challenges and 
Management Strategies. Springer Science+Business Media, New York.

Laulikitnont P. 2014. Evaluation of Mangrove Ecosystem Restoration Success in Southeast Asia. [Master's Projects]. University of San Francisco, California.

Lee SY, Dunn RJK, Young RA, Connolly RM, Dale PER, Dehayr R, Lemckert CJ, Mckinnon S, powell B, Teasdale PR, Welsh DT. 2006. Impact of urbanization on coastal wetland structure and function. Austral Ecol 31: 149-163.

Li MS, Mao LJ, Shen WJ, Liu SQ, Wei AS. 2013. Change and fragmentation trends of Zhanjiang mangrove forests in Southern China using multi-temporal Landsat imagery (1977-2010). Estuar Coast Shelf Sci 130: 111-120.

Miettinen J, Shi C, Liew SC. 2016. Land cover distribution in the peatlands of Peninsular Malaysia, Sumatra and Borneo in 2015 with changes since 1990. Glob Ecol Conserv 6: 67-78.

Motamedi S, Hashim R, Zakaria R, Song K, Sofawi B. 2014. Long-term assessment of an innovative mangrove rehabilitation project: case study on Carey Island, Malaysia. Sci World J 2014: 1-12.

Mukherjee N, Sutherland WJ, Khan MNI, Berger U, Schmitz N, Dahdouh-Guebas F, Koedam N. 2014. Using expert knowledge and modeling to define mangrove composition, functioning, and threats and estimate time frame for recovery. Ecol Evol 4 (11): 2247-2262.

National Coordinating Agency for Survey and Mapping, Republic of Indonesia. 2009. Peta Mangroves Indonesia. Pusat Survey Sumber Daya Alam Laut, Badan Koordinasi Survey dan Pemetaan Nasional, Cibinong. [Indonesian]

Nfotabong-Atheull A, Din N, Dahdouh-Guebas F. 2013. Qualitative and quantitative characterization of mangrove vegetation structure and dynamics in a peri-urban setting of Douala (Cameroon): an approach using air-borne imagery. Estuar Coast 36: 1181-1192.
Onrizal, Kusmana C. 2008. Ecological study on mangrove forest in East Coast of North Sumatra. Biodiversitas 9 (1): 25-29. [Indonesian]

Piou C, Feller IC, Berger U, Chi F. 2006. Zonation patterns of Belizean offshore mangrove forests 41 years after a catastrophic hurricane. Biotropica 38 (3): 365-374.

Rahman AF, Dragoni D, Didan K, Barreto-Munoz A, Hutabarat JA. 2013. Detecting large scale conversion of mangroves to aquaculture with change point and mixed-pixel analyses of high-fidelity MODIS data. Remote Sens Environ 130: 96-107.

Satyanarayana B, Mulder S, Jayatissa LP, Dahdouh-Guebas F. 2013. Are the mangroves in the Galle-Unawatuna area (Sri Lanka) at risk? A social-ecological approach involving local stakeholders for a better conservation policy. Ocean Coast Manag 71: 225-37.

Setyawan AD, Indrowuryatno, Wiryanto, Winarno K, Susilowati A. 2005. Mangrove plants in coastal area of Central Java: 2. Floristic composition and vegetation structure. Biodiversitas 6 (3): 194-198. [Indonesian]

Soepraptohardjo M, Soekardi M, Kurnia HD, Suhardjo S. 1979. Land and Soil Resources in Sumatra and Its Potential. Agricultural Research Consultation for Support of Sumatra Development, Lembaga Penelitian Tanah, Bogor. [Indonesian]

Strauch AM, Cohen S, Ellmore GS. 2012. Environmental influences on the distribution of mangroves on Bahamas Island. J Wetl Ecol 6: 1624.

Thu PM, Populus J. 2007. Status and changes of mangrove forest in Mekong Delta: case study in Tra Vinh, Vietnam. Estuar Coast Shelf Sci 71: 98-109.

Walters BB, Ronnback P, Kovacs JM, Crona B, Hussain SA, Badola R, Primavera JH, Barbier E, Dahdouh-Guebas F. 2008. Ethnobiology, socio-economics and management of mangrove forests: a review. Aquat Bot 89: 220-236. 